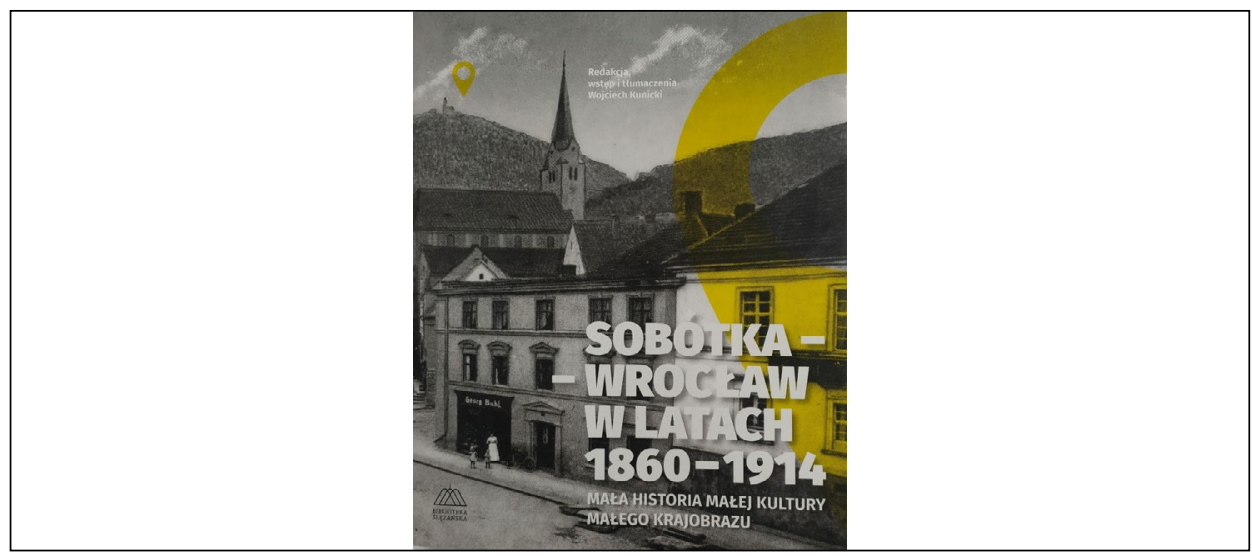

\title{
Z dziejów metropolii
}

https://doi.org/10.19195/2084-4107.15.27

[rec.] Sobótka - Wrocław w latach 1860-1914. Mała historia małej kultury małego krajobrazu, red., wstęp i przeł. Wojciech Kunicki, Wydawnictwo Muzeum Ślężańskiego, Sobótka 2020.

From the history of the metropolis

Słowa-klucze: Ślęża, Wrocław, metropolia, peryferie

Keywords: Mount Ślęża, Wrocław, metropolis, periphery

Naczelną tezą publikacji z serii „Biblioteka Ślężańska” jest konstatacja, iż Wrocław, Sobótka i Ślęża należą do jednej metropolii z nadodrzańskim miastem jako jej centrum oraz z masywem górskim oraz miasteczkiem i innymi miejscowościami u tegoż podnóża jako najbardziej odległymi jego peryferiami. Wojciech Kunicki odróżnia przy tym dwa typy peryferii. Pierwszy ma być noclegownią dla organizmu osiedleńczego, drugi zaś — służyć przede wszystkim celom rekreacyjnym i taki charakter ma obszar na południe od Wrocławia stanowiący przedmiot zainteresowania zaproponowanego przez znanego historyka literatury dyskursu. Autor obszernego wprowadzenia funkcję ową określa jako proces spowolniania, wskazując na wiele przeznaczeń takiego rodzaju peryferii. Są to turystyka, coś, co proponuje określić jako „daczowanie”, a także role parku i uzdrowiska. Wrocławski germanista traktuje przy tym zbudowana pod koniec XIX wieku linię kolejową do Sobótki i Świdnicy jako swoiście rozumiane metro bądź, chyba bardziej adekwatnie, ze względu na jej naziemny typ jako kolejkę podmiejską. Jakkolwiek bowiem istniały, według autora, we Wrocławiu firmy spedycyjne umożliwiające wyjazd do Sobótki inaczej niż koleją, to zapewne 
otwarcie możliwości szybszej i wygodniejszej podróży, stały rozkład jazdy układany z myślą o pragnących oderwać się od uciążliwych obowiązków codziennych wrocławian zintensyfikowały i wzmocniły związek okolic Ślęży z centrum metropolii, gdyż organizacja transportu to ważny komponent ożywiający rzeczywiste, a nie tylko potencjalne współoddziaływanie ośrodka i jego peryferii. Na jakość i spójność związku centrum i miejsc od niego oddalonych wpływała jednak także aktywność w tym zakresie także mieszkańców obszaru spowolnienia. Dobrym tego przykładem jest fakt, że inicjatywa utworzenia Ślężańskiego Towarzystwa Górskiego wyszła nie od wrocławian, ale od jednego z członków Świdnickiego Towarzystwa Górskiego, doktora Worthmanna, który wezwał Maxa Löbella z Sobótki, aby zorganizować u stóp Ślęży sekcję tegoż Towarzystwa. Pomysł ten zaaprobował burmistrz Sobótki Kühn i doprowadził do utworzenia w 1885 roku Zobten-Gebirgs-Verein. Trzeba podkreślić, że organizacja owa była rówieśniczką sobótczańskiej kolei i stanowiła niejako próbę pokierowania coraz większych grup wrocławskich (i nie tylko) turystów wysiadających z pociągów i zwiedzających Ślężę z jej okolicami. Wojciech Kunicki zaznacza, że w 1901 roku z Grupy Miejscowej Stowarzyszenia Sobóckiego wyodrębniło się ZGV Breslau, do którego wstąpiła znaczna część wrocławskich elit z nadburmistrzem Georgiem Benderem. ZGV miało więc od początku XX wieku dwa oddziały: centralny oraz peryferyjny, a ich rozwój i działalność wskazywały na coraz większe znaczenie Sobótki i jej okolic dla metropolii. O działalności ZGV można skonstatować z przetłumaczonych przez germanistę i zamieszczonych w "Antologii” sprawozdań Ślężańskiego Towarzystwa Górskiego. Organizacja „owa”, kiedy tylko ukonstytuowała się i nieco okrzepła, a więc w 1886 roku, podjęła wiele działań praktycznych ułatwiających życie turystów. Polegały one na ustawieniu drogowskazów, ławek w punktach widokowych (także na innych górach masywu), sporządzeniu listy mieszkań letniskowych, doprowadzeniu do wydania mapy, na której naniesiono nowe punkty widokowe i drogi, ulepszono stare i budowano nowe trasy piesze, zamontowano solidną balustradę na Ślęży. Z inicjatywy ZGV drukowano też górskie przewodniki. Ich treść Wojciech Kunicki dokładnie omawia w obszernym Wstępie, analizując różnice pomiędzy kilkoma ich wydaniami. Pierwszy przewodnik ukazał się w Sobótce w 1885 roku. Nie był on jeszcze oficjalnym organem wydawniczym $Z G V$, ale - jak uważa germanista - powstał we współpracy z tą organizacją. Książka opracowana przez Augusta Gühmanna zawierała nie tylko praktyczne wskazówki w rodzaju opisu tras i widoków górskich, miejsc zakwaterowania w Sobótce i okolicach, ostrzeżeń, by nie zaprószyć ognia w lesie i nie przebywać na szczycie więcej niż dwie godziny, ale także dane historyczne oraz teksty literackie związane tematycznie z regionem Ślęży. Gühmann przekazał w tymże przewodniku informacje o pierwotnej nazwie góry (Zlencz), Piotrze Włoście, założycielu pierwszego klasztoru na Górze Sobotniej, budowlach sakralnych z nią związanych, teoriach naukowych tłumaczących pochodzenie pogańskich rzeźb tam oglądanych (między innymi slawisty Władysława Nehringa), legendach ślężańskich, wreszcie — ważnych postaciach 
historycznych, które zdobyły kiedyś szczyt masywu. Nie omieszkał też autor omówić historii Sobótki oraz dziejów okolicznych wiosek. Wojciech Kunicki zwraca uwagę, że dyskurs Gühmanna był źródłowo udokumentowany dzięki cytowaniu między innymi najważniejszych dla tegoż regionu monografii $G e-$ schichte Schlesien (Historii Śląska) Colmara Grünhagena czy też Góry Ślęży i jej okolice Moritza Sadebecka. Przewodnik Gühmanna otwierał wiersz historyczny śląskiego poety Roberta Rösslera De Heemte (Bliska ojczyzna), gdzie śląski kraik został nazwany „ogrodem Boga”. Tego typu idealizacja terenu na pewno sprzyjała popularyzowaniu wśród turystów metropolitalnych peryferii. Bogactwem zawartości przewodnika Augusta Gühmanna tłumaczy Wojciech Kunicki czysto praktyczny charakter pierwszych dwóch wydań przewodników ZGV, zawierających między innymi rozkłady jazdy pociągów na trasie z Wrocławia do Świdnicy przez Sobótkę, taryfy dorożek, objaśnienia do załączonej mapy turystycznej, opis tras górskich w Masywie Ślęży, zwięzłe przedstawienie Sobótki i innych miejscowości wraz z ich zabytkami, a także informacje o florze regionu, roślinach, jakie wędrowcy mogą spotkać przy szlakach. Zwięzły i konkretny charakter przewodnika dopełnił spis pensjonatów, kwater prywatnych, restauracji i sklepów. W kontraście do drugiego wydania publikacji ZGV (1895) wrocławski germanista wskazuje na odmienną poetykę edycji czwartej (1904), w której autorem części wprowadzającej był wrocławski nauczyciel Paul Fiedler. W jego dyskursie Wojciech Kunicki zauważył dydaktyzację niemieckiej historii, a więc fakt, że drugim praktycznym celem publikacji oprócz wspierania ruchu turystycznego stała się niemiecka propaganda polityczna przejawiająca się chociażby w akcentowaniu, że planowana w tamtym rejonie wieża ku czci Bismarcka „głosić będzie jedność Niemiec, siłę, moc na skalę światową" (s. 21). Kontekstem dla reklamowania uroków Masywu Ślęży i okolic stała się więc ideologia ojczyźniana i narodowa. Redaktor „Biblioteki Ślężańskiej” zauważył we Wstępie, że wydanie z 1904 roku jest znakomite pod względem estetycznym, zawiera bowiem reprodukcje obrazów niemieckich pejzażystów ukazujących w swoich dziełach omawiany teren, takich jak Carl Ernest Morgenstern, Theodor Blache, Hans Dressler. Rewelacyjne było, według Wojciecha Kunickiego, zdjęcie zamku w Górce ujętego od dołu, od stawu browarniczego, „który na pierwszym planie istnieje jako coś w rodzaju romantycznego jeziora" (s. 22). Praktycznym walorem przewodnika stało się natomiast najbardziej szczegółowe ze wszystkich wydań omówienie szlaków turystycznych i leżących nieopodal miejscowości. Natomiast kolejne, piąte wydanie przewodnika z 1908 roku było już dziełem jednego tylko autora, Paula Fiedlera, chociaż zawierało też liczne ryciny - wykonane przez Carla Kicka i Alberta Beyera. Można było na nich oglądać między innymi nowe schronisko na szczycie Ślęży należące do Hassego, a także kolumnę Bismarcka (na dzisiejszej Wieżycy), zbudowaną rok wcześniej. W części praktycznej rozkład jazdy pociągów został uzupełniony przez tabelę czasową wycieczek pieszych. Specyfika opisu tras była też inna, to jest - bardziej nasycona wiadomościami historycznymi, na niekorzyść wiedzy z zakresu geologii czy botaniki. Przewodnik ten jawił się więc jako 
„historia kultury” omawianego terenu. Wojciech Kunicki zauważył też, że krój liter na okładce miał charakter secesyjny, a więc podlegał wpływowi aktualnego prądu artystycznego. Opis przewodników dokonany we Wstępie tomu „Biblioteki Ślężańskiej" jest bogato ilustrowany reprodukcjami z owych publikacji, co umożliwia dzisiejszemu odbiorcy uzyskanie pełnego wyobrażenia wydanych ponad 100 lat temu książek związanych tematycznie ze Ślężą i jej okolicami. Podobnie bogato ilustrowany jest dyskurs Wojciecha Kunickiego dotyczący widokówek ślężańskich. Widniały na nich nie tylko zdjęcia fragmentów pejzaży czy zabytków kultury, ale także reprodukcje obrazów wybitnych malarzy, między innymi C.E. Morgensterna czy też C. Fibigera - niektóre z nich (należące do zbiorów autora $W$ stępu) posiadają dużą wartość archiwalną, jeśli chociażby ukazują obiekty, które do dzisiaj nie przetrwały, jak widokówka ze schroniskiem młodzieżowym w Sulistrowiczkach. Na pewno wszystkie z nich są wyrazem gustów estetycznych epoki „ceniącej widoki nasycone lirycznością” (widokówka A. Beyera obrazująca nastrój wiosenny pod Ślężą). Do najcenniejszych artystycznie należy też kartka pocztowa stanowiąca wielopolową litografię Strzeblowa, wydana u L. Heege w Świdnicy. Wartość historyczną tych druków wzmacniają zdjęcia uwidocznionych na nich mieszkańców okolic Ślęży, a także stemple pocztowe i zapiski indywidualnych nadawców. Wojciech Kunicki zwraca uwagę na multimedialność tych pamiątek modernistycznych łączących elementy obrazowe, literackie i czasem nawet zapachowe. O tym ostatnim, sensualnym walorze niewiele, rzecz jasna, da się powiedzieć z samej lektury publikacji z serii „Biblioteki Ślężańskiej”. Zrozumiałe jest również, że literaturoznawca jako autor Wstępu i tłumaczeń poświęcił sporo miejsca pracom naukowym i dziełom artystycznym należącym do Matej historii małej kultury małego krajobrazu. Z główną tezą Wojciecha Kunickiego uznającą Sobótkę i okolice za peryferie i istotny czynnik budujący metropolitalność miasta nad Odrą skorelowany jest najbardziej obszerny tekst zamieszczony w Antologii, a więc Najstarsze dzieje wiosek leżacych u podnóża Góry Sobotniej, a należących do klasztoru kanoników reguły św. Augustyna na Piasku we Wrocławiu Hermanna Adlera. Druk ten dowodzi, jak ważne dla rozwoju gospodarczego położonych wokół Ślęży terenów było oddziaływanie Wrocławia, albowiem mnisi związani z centrum prowadzili tam nie tylko działania umacniające wiarę chrześcijańską (klasztor usytuowany w Górce), ale także poszczególni opaci lokowali na prawie niemieckim nowe wioski, trzebiąc porastające okolice masywu lasy i zaludniając Niemcami i Polakami obszar w niewielkim dotąd stopniu zasiedlony. Niektórzy przybysze pochodzili też z Flandrii. Po lekturze owego opartego na źródłach historycznych tekstu naukowego nasuwa się refleksja, iż już w średniowieczu właściciele musieli nierzadko spekulować poszczególnymi dobrami ziemskimi, gdyż przechodziły one z rąk do rąk często co kilka lat, a trudno znaleźć miejscowość związaną przez kilkaset wieków z jednym rodem szlacheckim. Do innych ważnych prac historycznych dotyczących omawianych peryferii należały wymienione we Wstępie: rozprawa Moritza Sadebecka Góra Ślęża i jej okolice czy chociażby czterotomowa 
edycja Schlesiche Sagen Richarda Kühnau. Warto nadmienić, że Kühnau był nauczycielem w królewskim Gimnazjum świętego Macieja we Wrocławiu, zaznacza się więc i tutaj rola centrum w procesie poznania peryferii.

Kwestią szczególnie interesującą dla literaturoznawcy (zarówno jako autora, jak i odbiorcy omawianej publikacji) jest literatura piękna związana tematycznie z okolicami Ślęży. Przegląd poezji odnoszącej się do peryferii metropolii rozpoczyna Wojciech Kunicki od wspomnienia najbardziej reprezentatywnych wierszy na widokówkach. Były to: utwór Karla von Holteia zatytułowany Der Zutabärg (Ślęża), a także Paula Fiedlera Die Waldkapelle, który poznajemy w tłumaczeniu polskim autora dyskursu (może szkoda, że przekład jest dokonany prozą), a także cytowany już wierszem w obu wersjach językowych liryk umieszczony na widokówce ukazującej schronisko na Ślęży, stworzony przez popularnego wówczas powieściopisarza, a jednocześnie profesora na Uniwersytecie Wrocławskim Feliksa Dahna. Wymienione zostały również wiersze okolicznościowe, wykorzystywane w sytuacjach biesiadnych przez Zobten-Gebirgs-Verein, to jest - Zobtenlied Carla Biberfelda oraz Die Wacht an der Oder (Straż nad Odrą) doktora Oswalda Baera, kierującego Towarzystwem Karkonoskim, a także $\mathrm{Na}$ 1 lutego 1902 Helene Dürlich z Sobótki. W utworze ostatniej z poetek mowa jest między innymi o krasnalach związanych, według ślężańskich legend, z nowym rejonem. Motyw ów pojawiał się w wielu tekstach artystycznych, między innymi w baśni z okolic Bielawy Der Herlaberg (Góra Skrzatów) oraz w balladzie Herrla (Skrzaty) autorstwa bliżej nieznanego H.J. im. Schm (druk w Schlesische Provinzialblaetter). Zgodnie z tym ostatnim dziełem, przetłumaczonym przez Wojciecha Kunickiego, krasnale zostały dowiezione na Ślężę taczką przez pewnego rzemieślnika, co uprawnia do wniosku, że gnomy musiały naprawdę niewiele ważyć. Jednak najbardziej rozległym dziełem, w którym wystąpiły te sympatyczne postacie, było to przeznaczone do wykonania scenicznego Mężowie w Górze Ślęży Carla Biberfelda. Tekst ów znalazł się w Antologii, przetłumaczony przez Wojciecha Kunickiego. Został on wystawiony podczas uroczystości Ślężańskiego Towarzystwa Górskiego we Wrocławiu 1 lutego 1902 roku. Biberfelda uznał Wojciech Kunicki za najważniejszego poetę okolicznościowego metropolii nad Odrą. Autor Wstępu omawia też zjawisko poezji powstającej w dialekcie śląskim. Nurt ten zapoczątkował Karl von Holtei, zaś najwybitniejszym poetą był, jak się wydaje, Robert Rössler, który napisał między innymi liryk De Heemte (Bliska ojczyzna) uznający Ślężę za centrum i symbol lokalnego raju. Twórca ten mieszkał w Sobótce, natomiast z Przemiłowem związany był Ernst Schenke. Do nurtu tego należał też August Lichter, syn chłopa z pobliskich Nasławic.

Trzy większe utwory powiązane tematycznie z okolicami Ślęży stworzyli w języku niemieckim poeci amatorzy; wrocławski germanista poświęca im więcej uwagi. Największe wrażenie zrobił na autorze tej recenzji poemat Der Dorfpfarrer (Proboszcz wiejski), określony przez Wojciecha Kunickiego jako cykl wierszy lirycznych; wydany pod pseudonimem Rabe von Zobten stanowił dzieło katolickiego księdza Roberta Klautschke. Utwór oparty został na motywach 
autobiograficznych i ukazuje życie chłopca urodzonego u podnóża Ślęży, dla którego w młodości spędzonej w szkołach wrocławskich góra jest „przestrzenią natchnienia" (s. 66), zaś u progu dorosłości podróż do kraju dzieciństwa przynosi utwierdzenie, dzięki wejściu na Ślężę i późniejszej modlitwie nad grobem matki, jego kapłańskiego powołania. Wojciech Kunicki docenia wartości artystyczne dzieła, jego fragmenty liryczne i opisowe. Szkoda, że całość utworu nie została przetłumaczona i zamieszczona w Antologii. Natomiast w poemacie Góra Sobótki Augusta Düffe pojawiły się legendarne postacie znane z ludowych przekazów dotyczących Ślęży i obecne choćby w utworze scenicznym Carla Biberfelda. Autorem trzeciego utworu z serii „amatorskiej” był właściciel firmy pogrzebowej z Wrocławia Alfred Ohagen. Stworzył on poemat Die Sobotenburg. Eine Dichtung von Zobten aus Schlesiens slavisch - germanischer Helden zeit (Zamek Sobótka. Poemat o Sobótce z śląskiego okresu heroicznego w epoce stowiańsko-germańskiej). Akcja utworu toczy się na przełomie VIII i IX wieku po Chrystusie, gdy na Ślęży mieszkało pogańskie plemię słowiańskich Sobotów, zaś u jej stóp miały kwitnąć osady gospodarnych germańskich Sylingów. Sobotami miał rządzić zły kapłan Swent. Wojciech Kunicki słusznie zauważył antysłowiańską i antypolską wymowę propagandową utworu:

To jasne, że protestancki autor przypisuje pogańskiemu kapłanowi cechy jak najbardziej katolickie, robiąc aluzje do rzymskiego zepsucia. Wiąże się to w sposób oczywisty z antykatolicką Hakatą. (s. 62-63)

Hakata była, jak wiadomo, niemiecką organizacją nacjonalistyczną wymierzoną w Polaków mieszkających w Niemczech na zagarniętych ziemiach polskich i łączyła krwiożerczy antypolonizm z antykatolicyzmem. Zapewne miała również wpływ na opisany we Wstępie epizod religijny, wiążący się z nieudaną próbą wyparcia dominującego w okolicach Sobótki Kościoła katolickiego przez parafię starokatolicką. W 1874 roku utworzono tak zwany Altkatolischer Verein, akt ten wiązał się ściśle z założeniami Kulturkampfu. Parafię starokatolicką rozwiązano w Sobótce w 1895 roku.

Dwudzielna, złożona z obszernego Wstępu naukowego oraz należącej do wielu dyskursów Antologii książka będąca tomem serii „Biblioteki Ślężańskiej” stanowi bogate źródło wiedzy i informacji o wymienionej w tytule części Dolnego Śląska mogące ze względu na swą wieloaspektowość zainteresować przedstawicieli wielu dyscyplin: historyków, literaturoznawców, historyków kultury, religioznawców, a także pisarzy zbierających materiały do powieści osnutych na tle dziejów regionu. Praca przybliża jednocześnie Ślężę i jej okolice także zwykłym turystom zamierzającym poznać miejsce będące symbolem regionu, umożliwiając bardziej świadome i pogłębione percypowanie obiektów natury i twórczego dziedzictwa cywilizacji.

Mirosław Olędzki ORCID: 0000-0003-0877-2075

Uniwersytet Wrocławski miroslaw.oledzki@uwr.edu.pl 